\title{
KEDUDUKAN HUKUM PERKAWINAN ADAT DAYAK LUNDAYEH
}

\section{DALAM HUKUM PERKAWINAN NASIONAL}

\author{
PARSI BILUNG \\ Fakultas Hukum Universitas Borneo Tarakan \\ Pasca Sarjana
}

\begin{abstract}
The procedure of marriage which is carried out in a customary manner and has existed before the State of Indonesia was established, as carried out by the Lundayeh Dayak community and until now is still maintained as a local culture of ancestral heritage is a tradition that is still highly upheld. Unification in the field of marital law through the establishment of Law No. 1 of 1974 has legal consequences for marital arrangements in Indonesia. So that it raises problems with the implementation of the marriage which is only carried out by customary Dayak Lundayeh.

The type of this research is normative juridical research, namely legal research to find the rule of law, legal principles and legal doctrine to answer the issue of juridical review of customary marriage and its legal consequences.

The results of the study indicate that the customary marriage law is a legal rule that regulates the forms of marriage, how to apply, marriage ceremonies and the termination of marriage. Based on the provisions of the regulations stipulated in Law No. 1 of 1974, marriages which are only carried out by Lundayeh customary without religious marriage are not valid, so the marriage cannot be performed either at the Office of Religious Affairs (KUA) for those who are Muslim and the Civil Registry Office (KCS) for those who are not Muslim.

The legal consequences of illegitimate marriages that are only carried out traditionally by the Lundayeh Dayak have an impact on the absence of recognition from the State for the marriage carried out, so that in the event of a dispute and dispute arising from the marriage, the State in this case the court cannot resolve the dispute resolution. settlement of marital disputes that are only carried out by custom, by the Lundayeh Dayak community carried out in local wisdom, namely through the customary court session
\end{abstract}

Keywords: Marriage, Adat, Dayak Lundayeh

\section{Pendahuluan}

Negara Indonesia sebagai Negara terbesar yang memiliki berbagai macam kultur, budaya dan adat, termasuk perbedaan dalam melakukan

tata cara perkawinan. Perbedaan dalam cara melakukan perkawinan 
sebagai pengaruh dari pengaturan perkawinan, membawa konsekuensi pada cara hidup kekeluargaan, kekerabatan dan harta kekayaan seseorang dalam kehidupan bermasyarakat. Setelah berlakunya undang-undang perkawinan, maka terjadi unifikasi hukum dalam perkawinan di Indonesia, dimana perkawinan mempunyai hubungan yang sangat erat dengan agama atau kerohanian. Pengaturan hukum tentang perkawinan telah berlaku sama terhadap semua warga Negara oleh karena itu, setiap warga negara harus patuh terhadap hukum yang berlaku, termasuk terhadap undang-undang perkawinan yang menjadi landasan untuk menciptakan kepastian hukum, baik dari sudut hukumkeluarga, harta benda, dan akibat hukum dari suatu perkawinan.

Keabsahan suatu perkawinan menurut undang-undang perkawinan adalah didasarkan pada hukum agama dan kepercayaan masing-masing, sehingga sejak berlakunya undang-undang perkawinan ini maka upacara perkawinan menurut hukum agama bersifat menentukan tentang sah atau tidaknya perkawinan itu. Hal ini berakibat banyak orang tidak melakukan pencatatan pada kantor catatan sipil. Berdasarkan penjelasan umum undang- undang perkawinan, mengenai pencatatan perkawinan, pencatatan kelahiran, pencatatan kematian merupakan suatu peristiwa penting bukan suatu peristiwa hukum. Pencatatan perkawinan dalam suatu akta merupakan akta nikah. Akta nikah adalah bukti tentang perkawinan dan merupakan alat bukti yang sempurna mengenai adanya perkawinan.

Hukum adat perkawinan sendiri mempunyai arti aturan-aturan hukum adat yang mengatur tentang bentuk-bentuk perkawinan, cara-cara pelamaran, upacara perkawinan dan putusnya perkawinan di Indonesia. Aturan-aturan hukum adat perkawinan diberbagai daerah di Indonesia berbeda-beda dikarenakan sifat kemasyarakatan, adat istiadat, agama dan kepercayaan masyarakat yang berbeda-beda. Disamping itu dikarenakan kemajuan jaman, selain adat perkawinan itu disana-sini 
sudah terjadi pergeseran-pergeseran, telah banyak juga terjadi perkawinan campuran antar suku, adat istiadat danagama yang berlainan. ${ }^{23}$

Perkawinan menurut hukum adat sendiri bisa merupakan urusan kerabat, keluarga, persekutuan, pribadi, bergantung pada tata susunan masyarakat yang bersangkutan. Namun setelah tahun 1974 terjadi unifikasi di bidang hukum perkawinan dengan lahirnya Undang-Undang Nomor 1 tahun 1974, yang terdiri dari XIV Bab dan 67 pasal. Undangundang tersebut mengatur tentang dasar-dasar perkawinan, syarat-syarat perkawinan, pencegahan perkawinan, batalnya perkawinan, perjanjian perkawinan, hak dan kewajiban suami isteri, harta dan benda dalam perkawinan, putusnya perkawinan serta akibatnya, kedudukan anak, perwalian, ketentuan lain, ketentuan peralihan dan ketentuan penutup. Serta Peraturan Pemerintah Nomor 9 tahun 1975 tentang Pelaksanaan Undang-Undang Nomor 1 tahun1974. Namun, peraturan perundangan tersebut tidak diatur tentang bentuk bentuk perkawinan, upacara-upacara perkawinan, cara peminangan dilakukan dan lainnya yang kesemuanya itu masih berada dalam ruang lingkup hukum adat. ${ }^{24}$

Hukum adat lokal perkawinan bukan hanya merupakan perbuatan social, kultur, magis-relijius tetapi juga perbuatan hukum. disebut sebagai perbuatan social karena perkawinan itu merupakan produk sosial. Perbuatan sosial artinya secara sosiologis perkawinan mengikat semua unsur dalam kehidupan social, baik individu, individuindividu maupun masyarakat, bahkan masyarakat itu sendiri. Disebut perbuatan magis-relijius karena dalam perkawinan melibatkan roh-roh leluhur dan agama. Ada upacara dan ritual yang wajib dilakukan agar

${ }^{23}$ Hilman Hadikusuma,Pengantar Ilmu Hukum Adat Indonesia,Mandar Maju,Bandung, 2003, h. 176

${ }^{24}$ Ibid 
supaya selamat baik dalam prosesi perkawinan maupun dalam perjalanan rumah tangga dari pasangan yang melangsungkan perkawinan tersebut. ${ }^{25}$

Secara antropologis, perkawinan merupakan produk budaya dan peradaban manusia. Peradaban dan kebudayaan itu dapat dilihat dari seni budaya dan penataan perilaku budaya dan peradaban. Dari segi ini, menunjukkan perbedaan besar antara manusia dengan hewan misalnya adalah perkawinan. Hubungan seksual antara suami istri yang dilakukan oleh manusia ada aturan normatifnya yaitu perkawinan yang disaksikan dan disahkan. Sedangkan hubungan seksual diantara binatang tidak mengenal aturan atau kaedah perkawinan. ${ }^{26}$

Unifikasi dibidang hukum perkawinan membawa konsekuensi hukum bagi seluruh warga negara Indonesia harus menggunakan dasar Undang- Undang Nomor 1 tahun 1974 dalam mengadakan atau menyelenggarakan perkawinan, padahal sebenarnya mereka telah mempunyai hukum adat perkawinan sendiri. Dan sebelum adanya unifikasi di bidang perkawinan telah ada beberapa pluralisme perkawinan baik untuk masyarakat pribumi beragama Islam atau lain, pribumi yang beragama Kristen, Timur asing (Cina,Arab dan negara-negara timur tengah lain) dan golongan Eropa.

Unifikasi hukum perkawinan bersifat nasional, yang berlaku untuk seluruh Indonesia. Namun, disana sini, diberbagai daerah dan berbagai golongan masyarakat masih berlaku hukum perkawinan adat, apalagi Undang- undang Nomor 1 Tahun 1974 hanya mengatur hal-hal yang pokok saja dan tidak mengatur hal-hal yang bersifat khusus setempat.

Perkawinan adat Dayak Lundayeh, memiliki tata cara dan aturan perkawinan yang sudah ada sejak jaman nenek moyang dan sampai

${ }^{25}$ Dominikus Rato, Hukum Perkawinan dan Waris Adat di Indonesia, Laksbang

Pressindo, Yogyakarta, 2015, h. 29

${ }^{26}$ Ibid 
saat ini masih dijunjung tinggi oleh masyarakat Dayak Lundayeh dalam melaksanakan perkawinan adat. Salah satu tradisi perkawinan adat Dayak Lundayeh yang masih dilaksanakan adalah adanya "purut", yaitu penggantian materi dari pihak laki-laki yang wajib diberikan kepada pihak perempuan, sebagai pengganti mempelai perempuan yang diberikan kepada orang tua dan keluarga dari pihak perempuan.

Tata cara perkawinan yang hanya dilakukan secara adat yang sudah ada sebelum Negara Indonesia berdiri, seperti yang dilaksanakan oleh masyarakat Dayak Lundayeh dan sampai saat ini masih tetap terjaga sebagai budaya lokal warisan nenek moyang merupakan tradisi yang tetap dijunjung tinggi Keabsahan perkawinan berdasarkan Pasal 2 ayat (1) Undang-Undang Nomor 1 Tahun 1974 menyebutkan bahwa "perkawinan adalah sah apabila dilakukan menurut hukum masing-masing agama dan kepercayaannyan itu”, selanjutnya ayat (2) menyebutkan “Tiap-tiap perkawinan dicatat menurut peraturan perundang-undangan yang berlaku". Namun, bagi sebagian masyarakat Dayak Lundayeh hanya melaksanakan perkawinan secara adat tanpa melaksanakan perkawinan secara keagamaan yang secara otomatis tidak melakukan pencatatan perkawinannya pada pencatatan sipil.

\section{Rumusan Masalah}

Berdasarkan uraian latar belakang masalah tersebut diatas, maka penulis merumuskan permasalahan bagaimanakah Kedudukan hukum perkawinan adat Dayak Lundayeh dalam hukum perkawinan nasional dan Akibat hukum Perkawinan yang hanya dilaksanakan berdasarkan perkawinan adat Dayak Lundayeh.

\section{Metode Penelitian}


Jenis dalam penelitian ini adalah penelitian yuridis normative, yaitu penelitian hukum untuk menemukan aturan hukum, prinsip hukum maupun doktrin hukum untuk menjawab permasalahan tinjauan yuridis terhadap perkawinan adat dan akibat hukumnya.

Pendekatan dilakukan dengan menelaah Undang-undang dan peraturan lainnya yang mengatur tentang perkawinan. Pendekatan Undang-undang untuk mengkaji dan menganalisis peraturan perundang-undangan yang berlaku untuk mencari rasio logis dan dasar ontologis lahirnya undang-undang tersebut. Pendekatan mempelajari pandangan dan doktrin dalam ilmu hukum untuk dapat menemukan ide yang melahirkan pengertian hukum, konsep hukum dan asas hukum yang relevan serta sebagai dasar dalam membangun argumentasi hukum untuk memecahkan permasalahan perkawinan adat dan akibat hukumnya secara khusus pada adat Dayak Lundayeh.

\section{PEMBAHASAN}

\section{A. Hukum Perkawinan Adat}

Undang-Undang Nomor 1 Tahun 1974 tidak mengatur tentang bentuk perkawinan, cara peminangan dan upacara perkawinan, dimana ketiga hal tersebut masih berada dalam ruang lingkup hukum adat, sehingga dengan berlakunya Undang-Undang Nomor 1 Tahun 1974, hukum perkawinan adat masih berlaku dimasyarakat. Bentuk perkawinan adat dapat dibedakan menjadi bentuk perkawinan adat masyarakat patrilineal, matrilineal dan parental.

1. Bentuk Perkawinan Masyarakat Hukum Patrilineal

Menurut kekerabatan masyarakat patrilineal, bentuk perkawinannya adalah perkawinan jujur. Perkawinan jujur adalah perkawinan dengan pemberian atau pembayaran perkawinan dari pihak laki-laki kepada pihak perempuan. 
Maksud dari pembayaran perkawinan adalah sebagai pertanda atau lambang diputuskannya hubungan kekeluargaan istri dengan orang tuanya, saudarasaudaranya, bahkan masyarakatnya. Sehingga tujuan pembayaran perkawinan adalah untuk memindahkan keanggotaan kerabat wanita yang dilepas dari kelompok kerabatnya dan masuk ke dalam lingkungan kerabat pihak suami, dan juga anak-anak yang akan dilahirkan dari perkawinan itu akan menarik garis keturunan dari pihak bapaknya.

2. Bentuk Perkawinan Masyarakat Hukum Matrilineal

Bentuk perkawinan pada masyarakat matrilineal bertujuan untuk mempertahankan garis keturunan pihak ibu. Calon mempelai laki-laki dan kerabatnya tidak memberikan jujur kepada pihak perempuan. Sejak perkawinan suami dan istri tetap dalam keluarga kerabat masing-masing, tetapi anak keturunannya masuk keluarga atau kerabat pihak istri dan pihak bapak tidak mempunyai kekuasaan terhadap anak-anaknya.

3. Bentuk Perkawinan Masyarakat Bilateral

Bentuk perkawinan masyarakat bilateral ialah perkawinan bebas atau mandiri. Setelah perkawinan suami dan istri memisahkan diri dari kekuasaan orang tua dan kerabat masing-masing untuk membangun keluarga atau rumah tangga sendiri.

\section{B. Hukum Perkawinan di Indonesia}


Perkawinan di Indonesia diatur dalam peraturan perundang-undangan mulai dari undang-undang sampai dengan peraturan pelaksananya sebagai berikut:

1. Undang-Undang Nomor 1 Tahun 1974

Undang-undang perkawinan nasional yang sekaligus menampung prinsip-prinsip dan memberikan landasan hukum perkawinan yang selama ini menjadi pegangan dan telah berlaku bagi berbagai golongan dalam masyarakat di Indonesia.Undang-Undang Nomor 1 Tahun 1974 mengatur tentang dasar- dasar perkawinan, syaratsyarat perkawinan, pencegahan perkawinan batalnya perkawinan, perjanjian perkawinan, hak dan kewajiban suami isteri, harta dan benda dalam perkawinan, putusnya perkawinan serta akibatnya, kedudukan anak, perwalian, ketentuan lain, ketentuan peralihan dan ketentuan penutup.

2. Peraturan Pemerintah Nomor 9 Tahun 1975 tentang Pelaksanaan Undang- Undang Nomor 1 Tahun 1974 Tentang Perkawinan

Peraturan Pemerintah Nomor 9 Tahun 1975 merupakan peraturan pelaksana dari Undang-Undang Nomor 1 Tahun 1974 yang secara efektif masih diperlukan peraturan-peraturan pelaksanaan, antara lain yang menyangkut masalah pencatatan perkawinan, tatacara pelaksanaan perkawinan, tatacara perceraian, cara mengajukan gugatan perceraian, tenggang waktu bagi wanita yang mengalami putus perkawinan, pembatalan perkawinan dan ketentuan dalam hal seorang suami beristeri lebih dari seorang dan sebagainya.

\section{Adat Dayak Lundayeh}


Pada umumnya, masyarakat Dayak Lundayeh dalam hal ini yang hidupdi wilayah administratif Kabupaten Malinau mengambil suatu keputusan melalui suatu proses musyawarah yang bersifat terbuka. Dalam proses musyawarah ini, pemimpin adat biasanya bertindak sebagai pemimpin musyawarah dan semua warga memiliki hak untuk berbicara.

Banyak pemimpin adat saat ini juga menduduki jabatan di pemerintahan formal negara, seperti kepala desa, dan lain-lain. Walaupun di satu sisi ia berperan sebagai kepanjangan tangan pemerintahan formal dan di sisi lain ia merupakan pimpinan tradisional dikomunitasnya, kepala suku lebih banyak menunjukkan sikap sebagai seorang fasilitator yang selalu menjaga harmoni dan keselamatan anggota masyarakat yang berada di dalam komunitasnya. Di banyak komunitas sekilas dapat terlihat bahwa sang kepala suku sepertinya merupakan pemain tunggal yang menentukan secara sendiri semua kebijakan yang berlaku dikomunitas bersangkutan. Namun dengan sedikit kemampuan untuk menyelam lebih jauh ke dalam untuk melihat realitas sesungguhnya, akan segera terlihat bahwa kepala suku atau kepala adat dalam mengemban tugasnya membutuhkan banyak orang untuk melakukan kegiatan-kegiatan yang bertujuan menjaga harmoni kehidupan di dalam komunitas masyarakat adat yang dimpimpinnya. Dalam situasi demikian, kepala suku ibarat dirijen dalam paduan suara yang memimpin berjalannya segenap tata aturan.

Jika hendak melakukan suatu kegiatan, sebagian besar kepala suku atau kepala adat ini mengajak seluruh anggota komunitas yang dimpimpinnya untuk mendiskusikannya dalam suatu proses musyawarah. Ketika keputusan tercapai, sang kepala suku atau kepala adat memiliki peran penting dimana ia harus 
mengamankan dan menjalankan hasil musyawarah tersebut. Bila ada yang melawan maka kepala suku atau kepala adat memiliki wewenang untuk menegur, menertibkan bahkan bisa saja warga yang melawan akan dibawa ke sidang adat. Tugas- tugas penting yang harus dilakukan oleh seorang kepala suku atau kepala adat dalam menjaga dan memelihara harmoni sebagai berikut: ${ }^{27}$

a. Menyelesaikan sengketa adat dalam urusan perkawinan, perselisihan antar warga dan pelanggaran hukum adat lainya

b. Menyelesaikan konflik antar komunitas yang bisa saja berakhir dengan pengambilan sumpah dengan upacara adat seperti memotong anjing atau sumpah dengan menyelam

c. Melindungi wilayah adat dan kekayaan alam yang terkandung di dalam wilayah adat yang dipimpinnya.

1. Perkawinan Adat Dayak Lundayeh

Bagi masyarakat adat Dayak Lundayeh perkawinan merupakan salah satu peristiwa penting dalam kehidupan secara pribadi, keluarga maupun masyarakat. Perkawinan bukan hanya berkenaan dengan peristiwa yang berhubungan dengan pribadi antara seorang laki-laki dan seorang perempuan, akan tetapi juga menyangkut antar saudara, orang tua, dan keluarga besar, bahkan masyarakat. Perkawinan pada masyarakat adat Dayak Lundayeh masih memegang kuat tradisi warisan dari leluhur, salah satu ciri bentuk perkawinan pada masyarakat adat Dayak Lundayeh adalah adanya "purut" sebagai bagian yang tidak terpisahkan dari tradisi perkawinan adat Dayak Lundayeh, seperti informasi yang disampaikan oleh Bapak Markus Lafa selaku peminang sebagai

${ }^{27}$ Wawancara dengan Bapak Frani Sinau selaku WakilKetua Lembaga Adat Dayak Lundayeh Kabupaten Malinau tanggal 17 Juli 2017 pukul 11.00 wite 
berikut "Purut adalah salah satu ciri yang ada dalam perkawinan adat Dayak Lundayeh, purut merupakan bentuk pembayaran dari pihak laki- laki yang diberikan kepada pihak perempuan diberikan dalam bentuk uang maupun barang, dengan adanya purut menjadi ikatan dan restu yang diberikan dari masing-masing keluarga terhadap perkawinan yang dilaksanakan". Pemberian purut pada perkawinan adat Dayak Lundayeh adalah bentuk perkawinan yang menggunakan jujur. Pada perkawinan ini pihak laki-laki harus memberikan uang atau barang kepada pihak perempuan. Bendabenda yang biasanya diberikan sebagai purut adalah benda-benda yang menjadi ciri khas masyarakat Dayak Lundayeh seperti tempayan, gong, dan benda-benda rumah tangga seperti mesin jahit, barang-barang elektronik rumah tangga, sampai kendaraan roda dua dan roda empat.

Pemberian purut dari pihak laki-laki kepada pihak keluarga memiliki makna dan fungsi yang kuat bagi adat masyarakat Dayak Lundayeh seperti yang disampaikan oleh Bapak Frani selaku wakil ketua adat Dayak Lundayeh kabupaten sebagai berikut:28

a. Purut berfungsi sebagai tanda ikatan

Pemberian purut dari keluarga laki-laki kepada pihak perempuan berfungsi sebagai tanda ikatan yang dilakukan antara kedua mempelai dan ikatan antar keluarga, sehingga dengan purut masingmasing orang tua mempelai memberikan sebutan "Arum". Purut dalam perkawinan adat Dayak Lundayeh akan memberikan ikatan selama perkawinan langgeng diantara kedua mempelai, sehingga ketika terjadi permasalahan dalam berkawinan yang berakibat pada perceraian yang diakibatkan oleh kesalahan pihak perempuan, maka pihak perempuan memiliki kewajiban untuk mengambalikan purut yang tekah diberikan oleh pihak laki-laki.

\footnotetext{
${ }^{28}$ Wawancara dengan Bapak Frani Sinau selaku WakilKetua Lembaga Adat Dayak Lundayeh Kabupaten Malinau tanggal 17 Juli 2017 pukul 11.00 wite
} 
b. Purut berfungsi sebagai tanda pelepasan mempelai perempuan kepada keluarga pihak laki-laki Perkawinan adat Dayak Lundayeh, purut berfungsi sebagai tanda pelepasan mempelai perempuan untuk diserahkan kepada keluarga laki- laki, dalam hal ini purut menandakan pembayaran yang diberikan oleh pihak laki-laki kepada pihak perempuan agar mempelai perempuan diserahkan kepada pihak laki-laki. Sebagai tanda pembayaran, kedua belah pihak akan melakukan tawar menawar terhadap purut yang diajukan pihak perempuan pada saat pembicaraan perencanaan perkawinan, jika kedua belah pihak telah menyepakati jumlah dan besaran purut, maka penyerahan purut akan diberikan pada saat pelaksanaan "Lubak Arum".

c. Purut berfungsi sebagai gotong royong

Purut yang diberikan oleh pihak laki-laki kepada pihak perempuan dalam bentuk uang dan barang relatif memiliki nilai yang besar, masyarakat adat Dayak Lundayeh memiliki tradisi untuk saling membantu dan gotong royong yang dilakukan pihak keluarga lakilaki untuk menyediakan purut yang akan diberikan kepada pihak perempuan.Keluarga besar dari pihak laki-laki akan melakukan pembahasan untuk membagi permintaan purut yang telah disepakai oleh kedua keluarga, pada umumnya pembagian jatah pemberian purut disesuaikan dengan kemampuan dari keluarga pihak laki-laki, artinya pemberian besaran purut dalam bentuk uang maupun jenis barang disesuaikan dengan tingkat perekonomian keluarga.

d. Purut menunjukkan status dan derajat keluarga

Pemberian purut berupa uang dan barang akan menunjukkan status dan derajat keluarga dari pihak yang memberikan purut, semakin tinggi nilai pirut yang diberikan akan menunjukkan derajat dan status yang semakin tinggi dan sebaliknya. 
e. Purut berfungsi sebagai utang-piutang

Masyarakat adat Dayak Lundayeh dari pihak keluarga laki-laki secara langsung maupun tidak langsung juga menempatkan purut sebagai utang-piutang, bantuan pemberian purut dari keluarga pihak lakilaki untuk membantu orang tua mempelai laki-laki adalah pembayaran utang atas bantuan purut yang pernah dilakukan orang tua pihak laki-laki kepada mereka. Bagi orang tua pihak laki-laki pemberian bantuan purut oleh keluarga merupakan utang yang harus mereka bayar suatu saat ketika pihak kelurga melakukan acara perkawinan. Pemberian purut dalam perkawinan adat Dayak Lundayeh yang dilaksanakan secara gotong-royong, bagi masyarakat adat Dayak Lundayeh memiliki makna kebersamaan dan kerukunan, namun bagi sebagian masyarakat Dayak Lundayeh, tradisi tersebut justru menimbulkan beban bagi mereka karena secara tidak langsung menimbulkan ikatan utangpiutang.

2. Tahapan Perkawinan Adat Dayak Lundayeh

Proses perkawinan adat Dayak Lundayeh mulai dari proses perkenalan sampai dengan pelaksanaan perkawinan memiliki tahapan secara terinci sebagai berikut: 29

a. Ngukap Tang

Tahap Ngukap Tang merupakan tahap awal atau berpacaran, pada tahap ini merupakan awal membicarakan hubungan pihak laki-laki dengan pihak perempuan. Untuk membuktikan keseriusan hubungan diantaranya, pihak laki-laki memberikan kain selendang dan tempayan kecil kepada pihak perempuan, dengan diterimanya barang-barang tersebut menunjukkan pihak keluarga perempuan merestui hubungan keduanya.

b. Nuduk

\footnotetext{
${ }^{29}$ Wawancara dengan Bapak Paulus Belapang selaku Ketua Lembaga Adat Dayak Lundayeh Kabupaten Malinau tanggal 11 Juli 2017 pukul 17.00 wite
} 
Nuduk merupakan tahap pelamaran atau peminangan untuk melanjutkan keseriusan hubungan antara pihak laki-laki dan perempuan. Untuk mengikat hubungan diantara keduanya dilakukan kegiatan nuduk. Pada kegiatan nuduk dilakukan pembicaraan antara pihak laki-laki dengan pihak perempuan terhadap perencanaan perkawinan, termasuk membahas dan menyepakati mengenai purut, besarnya dana dan barang yang harus disiapkan oleh pihak laki-laki untuk diberikan kepada pihak perempuan.

c. Burung atau kampak kayu Menandakan kesepakatan persiapan perkawinan dengan membuat Tebuku Uwe sebagai penanda jumlah hari menuju perkawinan. Biasanya dilakukan ikatan pada Tebuku Uwe sebanyak 100 ikatan yang menandakan 100 hari menuju perkawinan, setiap hari pihak laki-laki dan perempuan harus melepaskan satu ikatan Tebuku Uwe sehingga pada hari perkawinan ikatan pada Tebuku Uwe telah habis.

d. Nefed Menangang

Nefed Menangang adalah pembuatan miniatur burung yang diikat pada sebatang kayu, ketika menjelang prosesi perkawinan, yaitu ketika pihak laki-laki akan memasuki area tempat dilangsungkan perkawinan, pihak laki-laki terlebih dahulu harus menembak miniatur burung yang telh digantung tersebut dengan senapan angin, ketika miniatur burung dapat ditembak oleh pihak lakilaki, maka ia dapat memasuki area pelaksanaan adat perkawinan. Namun, jika pihak laki-laki tidak dapat menembak miniatur burung, maka batang pohon tempat digantungnya miniatur burung tersebut akan ditebang dan pihak laki-laki wajib meletakkan barang sebagai gantinya untuk dapat memasuki area pelaksanaan perkawinan adat 
e. Lubak Arum

Lubak Arum merupakan prosesi upacara perkawinan adat DayakLundayeh

f. Viwan

g. Viwan merupakan tahapan mengantar mempelai perempuan untuk diantar ke rumah mempelai laki-laki. Tahap ini menunjukkan pelepasan mempelai perempuan oleh pihak keluarga untuk diserahkan kepada mempelai laki-laki. Pada prosesi Viwan, pihak keluarga perempuan juga menyerahkan sebagian barang-barang yang telah diberikan oleh pihak lakilaki kepada mempelai laki-laki dan perempuan khususnya barang- barang rumah tangga sebagai bekal mereka untuk memulai kehidupan berumah tangga.

h. Eme Nanga

Perkawinan yang dilakukan secara adat Dayak Lundayeh memberikan ikatan keluarga antara pihak laki-laki dengan pihak keluarga perempuan. Ikatan tersebut dibuktikan dengan adanya saling bantu dan saling tolong (Eme Nangan) yang dilakukan keluarga pihak perempuan kepada keluarga pihak laki-laki ketika ada hajatan yang dilakukan oleh keluarga pihak perempuan. Bantuan yang diberikan oleh keluarga pihak perempuan berupa barang-barang seperti yang diberikan pihak laki-laki ketika diberikan kepada pihak perempuan.

i. Sanig

Sanig merupakan bantuan dari pihak keluarga laki-laki kepada pihak keluarga perempuan ketika ada keluarga perempuan yang melakukan perkawinan

D. Penyelesaian Sengketa Perkawinan Adat Dayak Lundayeh

Perkawinan yang hanya dilaksanakan secara adat Dayak Lundayeh adalah tidak sesuai dengan Undang-Undang Nomor 1 
Tahun 1974 karena tidak dilaksanakan secara keagamaan, sehingga perkawinan tersebut tidak dapat dilakukan pencatatan seperti yang diatur dalam Undang-undang perkawinan di Indonesia. Tidak sesuainya perkawinan berdasarkan UndangUndang Nomor 1 Tahun 1974 berdampak terhadap tidak adanya pengakuan dari Negara atas perkawinan yang dilakukan, sehingga jika terjadi perselisihan dan sengketa yang timbul akibat perkawinan tersebut, Negara dalam hal ini pengadilan tidak dapat menyelesaikan sengketa penyelesaian.

Pengadilan Negeri Malinau selama ini tidak dapat menyelesaikan sengketa perkawinan yang tidak tercatat seperti yang diatur menurut hukum perkawinan di Indonesia, seperti informasi yang disampaikan oleh Bapak Arief Budiman selaku Ketua Pengadilan Negeri Malinau sebagai berikut, "syarat kelengkapan kasus permasalahan perkawinan yang diajukan kepada pengadilan negeri adalah harus melampirkan berkas administrasi kependudukan seperti KTP, kartu keluarga, akte nikah, dan kelengkapan administrasi lainnya, tanpa kelengkapan administrasi kependudukan secara khusus surat nikah maka pengadilan tidak dapat memproses sengketa tersebut".

Informasi yang disampaikan diatas menunjukkan bahwa pengadilan negeri sebagai lembaga yang memiliki kewenangan yudikatif sebagai perwakilan Negara hanya dapat menyelesaikan permasalahan perkawinan yang sah dan tercatat seperti yang diatur dalam hukum positif di Indonesia.

Pengadilan negeri Kabupaten Malinau hanya akan memproses perkara sengketa perkawinan yang telah memiliki 
persyaratan administrasi perkawinan seperti yang diatur dalam Undang-undang nomor 1 Tahun 1974, yaitu: ${ }^{30}$

1. Perkawinan dilaksanakan menurut agama dan kepercayaan yang diakui di Indonesia

2. Perkawinan dilakukan pencatatan

Persyaratan formil penyelesaian sengketa di pengadilan negeri adalah kelengkapan surat nikah, tanpa adanya kelengkapan surat nikah maka pengadilan negeri tidak akan melakukan proses penyelesaian sengketa perkawinan.

Berdasarkan hukum positif di Indonesia perkawinan yang hanya dilakukan secara adat dianggap tidak sesuai dengan Undang-Undang Nomor1 Tahun 1974, sehingga dampak dan akibat dari perkawinan yang dilakukan dinyatakan tidak memiliki kekuatan hukum

3. Kedudukan anak

Perkawinan yang tidak sesuai dengan Undang-Undang Nomor 1Tahun 1974 akan mengakibatkan kedudukan anak tidak memiliki pengakuan yang sah secara hukum, anak yang dihasilkan dari perkawinan yang tidak sah akan dianggap sebagai anak diluar pernikahan.

Kedudukan anak diluar perkawinan hanya dapat diberikan pengakuan secara hukum jika perkawinan yang dilakukan oleh orang tuanya dilaksanakan secara sah berdasarkan Undang-undang Nomor 1 tahun 1974

2. Harta gono-gini

Perkawinan yang dilakukan tidak sesuai dengan UndangUndangNomor 1 Tahun 1974 akan berdampak terhadap tidak adanya pengakuansecara hukum terhadap harta benda yang dihasilkan selama pelaksanaan perkawinan (harta gono

\footnotetext{
${ }^{30}$ Wawancara dengan Bapak Arief Budiono selaku ketua pengadilan negeri Kabupaten Malinau, tanggal 7Agustusi 2017 pukul 09.00 wite
} 
gini)Pengadilan sebagai lembaga yudikatif hanya akan melakukan proses penyelesaian sengketa perkawinan yang dinyatakan sah berdasarkan Undang-undang Nomor 1 tahun 1974. Oleh karena itu, penyelesaian sengketa perkawinan yang hanya dilakukan secara adat, oleh masyarakat Dayak Lundayeh dilaksanakan secara kearifan lokal, yaitu melalui jalur sidang pengadilan adat.

Penyelesaian sengketa perkawinan adat Dayak Lundayeh yang tidak tercatat secara administrasi oleh Negara, selama ini diselesaikan melalui mekanisme pengadilan adat, seperti informasi yang disampaikan oleh bapak Bernadus Ganang selaku Bidang Hukum Adat Lembaga Adat Dayak Lundayeh Kabupaten Malinau, bahwa terdapat tahapan penyelesaian sengketa perkawinan secara adat sebagai berikut: 31

1. Sidang Adat Dayak Ludayeh Tingkat Desa

Sidang adat Dayak Lundayeh tingkat Desa merupakan lembaga peradilan adat tingkat pertama. Penyelesaian sengketa perkawinan untuk tahap pertama akan diselesaikan pada tingkat desa, seperti persidangan umumnya, pada sidang adat tingkat desa, pengurus adat Dayak Lundayeh tingkat Desa akan mengundang pihak suami beserta keluarga dan pihak istri beserta keluarga. Pada tahap ini, masing-masing pihak. diberikan kesempatan untuk menyampaikan pendapat, keluhan dan bukti-bukti yang dimiliki terhadap sengketa perkawinan mereka.

Sidang adat Dayak Lundayeh tingkat Desa dalam penyelesaian sengketa perkawinan akan berupaya untuk melakukan mediasi diantara kedua belah pihak untuk dapat

\footnotetext{
${ }^{31}$ Wawancara dengan Bapak Bernadus Ganang selaku Bidang Hukum Adat Lembaga Adat Dayak Lundayeh Kabupaten Malinau tanggal 6 Juli 2017 pukul 14.00 wite
} 
dilakukan perdamaian. Namun jika permasalahan sangat pelik, sidang adat tingkat Desa dapat juga memutuskan perceraian disertai dengan penyelesaian masalah anak dan harta suami istri.

2. Sidang Adat Dayak Lundayeh Tingkat Kecamatan

Sidang adat Dayak Lundayeh tingkat kecamatan merupakan lembaga sidang banding dari keputusan yang dihasilkan pada tingkat desa, pihak yang tidak puas atas keputusan sidang adat tingkat Desa dapat mengajukan banding pada tingkat kecamatan.

Pada sidang adat Dayak Lundayeh tingkat Kecamatan akan melakukan proses persidangan yang hamper serupa dengan sidang pada tingkat Desa, pada tingkat Kecamatan pihak-pihak yang bersengketa dapat mengajukan bukti-bukti tambahan dan pendapatnya masing- masing untuk disampaikan pada pengurus Adat Dayak Lundayeh tingkat Kecamatan.

3. Sidang Adat Dayak Lundayeh Tingkat Kabupaten

Sidang adat Dayak Lundayeh tingkat kabupaten merupakan lembaga sidang banding tingkat akhir dari keputusan yang dihasilkan pada tingkat desa dan kecamatan, pihak yang tidak puas atas keputusan sidang adat tingkat Desa dan kecamatan dapat mengajukan banding pada tingkat kabupaten.

Pada sidang adat Dayak Lundayeh tingkat kabupatenakan melakukan proses persidangan pada tingkat-tingkat sebelumnya, pada tingkat kabupaten pihak-pihak yang bersengketa dapat mengajukan bukti-bukti tambahan dan pendapatnya masing-masing untuk disampaikan pada pengurus Adat Dayak Lundayeh tingkat kabupaten. 
Penyelesaian sengketa perkawinan melalui sidang adat pada umumnya adalah untuk menyelesaikan sengketa perkawinan yang tidak memiliki akte nikah sebagai persyaratan formil hukum positif di Indonesia. Oleh karena itu, pengadilan tidak akan turut campur untuk melakukan proses penyelesaian sengketa perkawinan yang telah dilaksanakan melalui kearifan lokal yaitu sidang adat

\section{DAFTAR PUSTAKA}

Buku :

Abdulrahman, Hukum Adat Menurut Perundang-Undangan Republik Indonesia, Cendana Press, Jakarta, 1984.

B. Ter Haar, Asas-asas dan Susunan Hukum Adat, Terjemahan oleh Soebakti Poesponot, PT. Pradnya Paramita, Jakarta, 1985

CST Kansil, Pengantar Ilmu Hukum dan Tata Hukum Indonesia, Balai Pustaka, Jakarta, 2003.

Hilman Hadikusuma, Pengantar Ilmu Hukum Adat Indonesia, Mandar Maju, Bandung, 2014.

Mohamad Idris Ramulya, Hukum Perkawinan Islam, Bumi Aksara Sinar Grafika, Jakarta, 1995.

Rato Dominikus, Hukum Perkawinan dan Waris Adat di Indonesia, Laksbang

Pressindo, Yogyakarta

Saidus Syahar, Undang-Undang Perkawinan dan Masalah Pelaksanaannya, Alumni, Bandung, 1981,

Setiady Tolib, Intisari Hukum Adat Indonesia, Alfa Beta, Bandung, 2015

Soekanto. Soerjono. Hukum Adat Indonesia. Raja Grafindo, Jakarta, 2011. , Meninjau Hukum Adat Indonesia, Rajawali, Jakarta, 1985.

Soemiyati, Hukum Perkawinan Islam dan Undang-Undang Perkawinan, Liberty, Jakarta, 2007.

Soepomo, Hukum Adat di Indonesia, Pradnya Paramita, Jakarta, 1986. 
, Kedudukan Hukum Adat di Kemudian Hari, Makalah disajikan dalam Pidato Dies pada tanggal 17 Maret 1947, di Universitas Gadjah Mada Yogyakarta, Pustaka Rakyat, Jakarta, 1951

Sulastri Dewi, Pengantar Hukum Adat, Pustaka Setia, Bandung, 2015

Syahuri Taufiqurrohman, Legislasi Hukum Perkawinan di Indonesia, Prenadamedia Grup, Jakarta, 2013

Tim Penyusun, Kamus Besar Bahasa Indonesia, Gramedia Pustaka Utama, Jakarta, 2008.

Triwulan Tutik, Pengantar Ilmu Hukum, Prestasi Pustaka, Jakarta, 2006.

Van Vallenholen, Orientasi dalam Hukum Adat Indonesia, Jambatan, Jakarta,

1983

Wignjodipuro Soerojo, Pengantar dan Susunan Hukum Adat, Alumni, Bandung, 1978. 